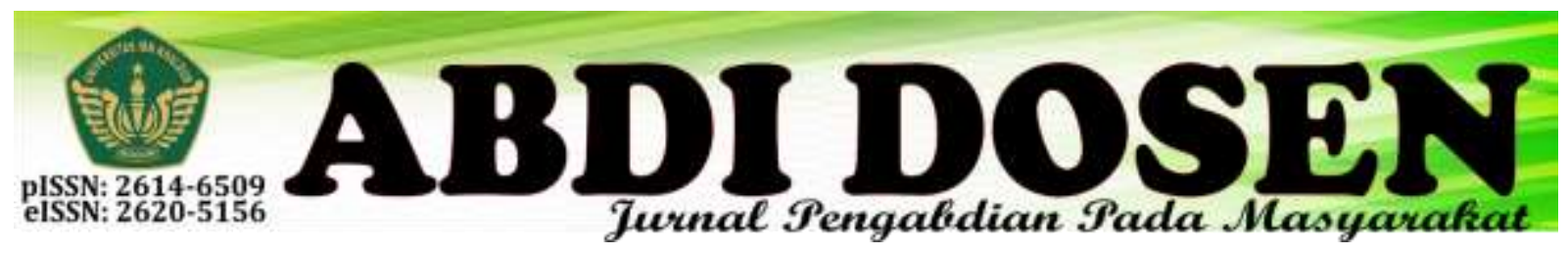

\title{
ETIKA DAKWAH PERSPEKTIF AL-QUR'AN SURAH AN-NAHL AYAT 125
}

\author{
Hendra \\ hendra@gmail.com \\ Universitas Paramadina Jakarta
}

\begin{abstract}
ABSTRAK
Al-Qur'an sebagai Ahkamus Syari'ah merupakan kitab penyempurna dari seluruh kitab- kitab yang Allah turunkan kepada para Nabi-Nya. Di dalamnya banyak memberikan inspirasi yang kuat agar manusia banyak melakukan penelitian tentang alam semesta dan seluruh isinya, berisi hukum-hukum ibadah dan muamalah dan juga diantaranya berisi tuntunan tentang metode berdakwah. Para mufassir berusaha menafsirkan ayat metode dakwah tersebut, dalam hal ini adalah surah An-Nahl ayat 125. Juga nanti pada bagian berikutnya akan dipaparkan pula etika berdakwah dari sisi makarim Syari'ah dari sudut perspektif Etika Ibnu Miskawaih, seorang tokoh yang dikenal sebagai Bapak etika dalam Islam. Contoh kongkrit dari ayat tadi dapat dilihat dari seorang manusia tauladan, yang langit pun sampai cemburu kepada bumi karena di bumi ada sosok teladan itu yaitu, Rasulullah Muhammad SAW.
\end{abstract}

Kata kunci: Etika, Dakwah, Al-Qur'an, An-Nahl ayat 125, Teladan.

\section{PENDAHULUAN}

Sangat penting bagi seorang da'i untuk mengenal masyarakat selaku obyek dakwah, sehingga untuk tercapainya kesuksesan suatu dakwah sangat terkait dengan metode yang disampaikan. Karenanya seorang da'i hendaknya memahami tentang obyek dakwah yang akan menjadi sasaran dakwahnya. Berikut ini akan penulis uraikan pendapat dari para pakar tentang pentingnya metode dakwah, agar dakwahnya itu berhasil.

Menurut Syeikh M. Abu al-Fath alBayanuni menyatakan bahwa urgensi metode dakwah adalah sebagai berikut: a).Terjaga dari penyimpangan dalam mengemban misi dakwah Islamiyyah. b).Dengan metode akan memperjelas visi dan misi dakwah. c).Untuk keseimbangan dan kelanjutan dakwah.
Menurut Syeikh Athif Faiz menyatakan mengenai pentingnya metode dakwah adalah merupakan langkah awal menuju izzul Islam sebagai manhaj Qur'ani, manhaj dimensi dan manhaj muhaddad (aturan yang teratur dan tertata rapi), agar tidak terjadi penyimpangan dalam berdakwah sekaligus sebagai khath fashil (titah pembeda) antara yang menuju ridho Allah dan yang menuju jalan kesesatan.

Smith Athif al-Zain menyampaikan tentang pentingnya metode dakwah adalah merupakan hal yang sangat penting dalam meluruskan misi dakwah yang selama ini terpuruk, padahal Al-Quran benar-benar 
mengajarkan metode khusus dalam penyebaran misi Islam ${ }^{1}$.

Sedangkan mengenai objek dakwah (mad'u), Muhammad Abduh membagi mad'u menjadi tiga kelompok, yaitu: ${ }^{2}$ 1).Golongan cendekiawan yang cinta kebenaran, dan dapat berpikir secar kritis, serta cepat menangkap persoalan. 2).Golongan awam, yaitu kebanyakan orang yang belum dapat berpikir secara kritis dan mendalam, belum dapat menangkap pengertian-pengertian yang tinggi.3).Golongan yang berbeda dengan kedua golongan tersebut, mereka senang membahas sesuatu, tetapi hanya dalam batas tertentu, dan tidak sanggup mendalami dengan benar.

Salah satu prinsip yang menjadi dasar metode dakwah terdapat dalam AlQur'an yaitu surah An-Nahl ayat 125. Sedangkan contoh teladan dakwah terbaik tentu terdapat pada dakwah Rasulullah yang telah sukses dalam menyiarkan Islam sebagai rahmatan lil'alamiin. Maka tulisan ini berjudul: "Etika Dakwah Pespektif AlQur'an Surah An-Nahl ayat 125'.

Menurut penulis, pembahasan ini penting untuk dikaji karena dapat dijadikan sebagai landasan teori metode dalam berdakwah. Adapun rumusan masalahnya adalah: "Bagaimanakah etika dakwah perspektif Al-Qur'an Surah An-Nahl ayat 125?".

Untuk menjawab rumusan masalah tersebut penulis akan memulainya dengan pembahasan surah An-Nahl ayat 125 dan terjemahnya. Kemudian akan dipaparkan pula mengenai penafsiran surah An-Nahl

${ }^{1}$ Erna ikawati, Metode Komunikasi Dakwah Dalam Pespektif Hadits, (Jurnal), (Jakarta. UIN syarif Hidayatullah: Hikmah, 2012), Vol. VI, h.127

${ }^{2}$ Erna Ekawati, Metode Komunikasi Dakwah Dalam Perspektif Hadits, h.127. ayat 125 tersebut menurut para mufassir. Juga akan dibahas tentang kajian ayat tersebut dari sisi etika menurut tokoh Ibnu Miskawaih, yang dikenal sebagai tokoh bapak etika dalam Islam. Pada bagian terakhir akan diuraikan pula tentang bagaimana kesuksesan dakwah Nabi Muhammad SAW dalam lintasan sejarah Islam.

Tulisan ini adalah penelitian dengan metode penelitian kepustakaan (library research) dengan sumbernya terdiri dari tiga macam, yaitu sumber primer, sumber pendukung primer dan sumber skunder. 


\section{PEMBAHASAN}

\section{A. SURAH AN-NAHL AYAT 125}

1. Teks An-Nahl ayat 125

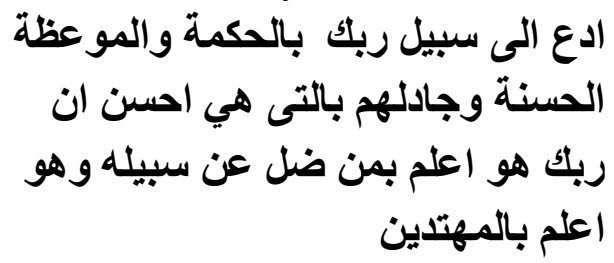

2. Terjemah An-Nahl ayat 125

"Serulah (manusia) kepada jalan

Tuhan-mu dengan hikmah dan pengajaran yang baik, dan berdebatlah dengan mereka dengan cara yang baik. Sesungguhnya Tuhan-mu, Dialah yang lebih Mengetahui siapa yang sesat dari jalan-Nya dan Dialah yang lebih Mengetahui siapa yang mendapat petunjuk". 3

3. Makna Kosa-kata An-Nahl Ayat $125^{4}$

دَعْوَةً (أَْْعُ Berasal dari kata

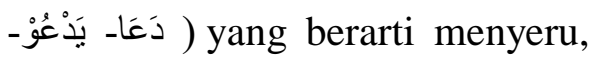
memanggil, mengajak, menjamu, (دَعَا إلَىى) artinya mengajak kepada دَاع yang mendo'a, yang menyeru, yang memanggil. ( دَعْوَةُ ) seruan,

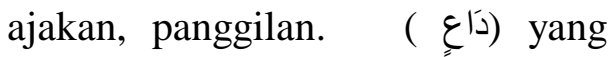
mengajak. Maksud dari kata ini adalah ajakan atau seruan yang diperintahkan kepada Nabi Muhammad SAW dari Allah SWT untuk mengajak umat manusia ke jalan yang ditunjukkan oleh Allah SWT yakni ajaran Islam.

$$
\text { Berasal dari kata }
$$

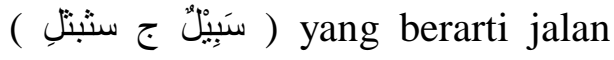

${ }^{3}$ Al-Qur'an dan Terjemahnya, Departemen Agama RI, (Bandung: CV. Diponegoro, 2006), Cet. X, h.224.

4Zain Fannani, Metode Pendidikan Dalam Al-Qur'an (Kajian Tafsir Surat An-Nahl Ayat 125), (Skripsi), (Jakarta: UIN Syarif Hidayatullah, 2014), h.37-39 raya. ( إبن السيل) orang berjalan, musafir. (سبيل الله ) perjuangan, menuntut ilmu, kebaikan-kebaiakn

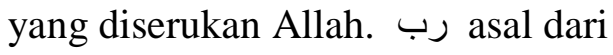
kata ( رَب-يرب - ربا ) yang berarti ارباب رب اب . mengasuh, memimpin. Tuhan, tuan, yang punya. (رب رباب Tuhan (pendidik) seluruh alam. Jadi yang dimaksud kalimat disini ialah kembali kejalan Allah SWT. Yaitu kembali kepada agama Allah SWT, sebagaimana yang diserukan oleh Nabi Muhammad SAW.

Berasal dari kata (حكم- بحكم- بكمة (حكم) yang berarti memerintah, menghukum. حكة Mengetahui yang benar, kata hikmah. Yang dimaksud kata hikmah disini adalah sebagai sesuatu yang apabila digunakan akan mendatangkan kemudahan dan keselamatan, serta menghalangi terjadinya mudharat atau kesulitan yang besar.

berasal dari

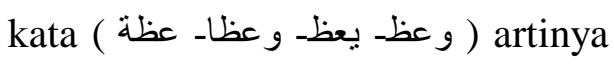
menasihati, mengajarinya.

اتعظ|nerima nasihat, pengajaran

عظة (جhutbah, nasihat, ucapan, و عظ ج) perkataan, nasihat, pengajaran ( واعظ ج وعا ظ ) yang memberi nasihat

pengajaran, nasihat. حسن- Berasal dari kata ( حسنة يحسن- حسنا ( yang berarti baik, bagus. (احس- حسن ) membaguskan حسن ج حسان yang baik, yang cantik ( حسنة ج حسنان ) perbuatan yang baik, kebaikan.

Berasal dari kata

جادل- مجادلة- جدالا 
berbantah, berdebat

perbantahan, perdebatan.

Berasal dari kata (

( حسن-يحسن-حسنا bagus (حسن- احسن) membaguskan (
ج) yang baik, yang cantik ( حسنة جحسنات ) perbuatan احسن ج احاسن ( yang baik, kebaikan yang lebih bagus.

\section{B. TAFSIR SURAH AN-NAHL AYAT 125 MENURUT PARA MUFASSIR}

Kata ( $\varepsilon \dot{\imath}$ ) merupakan bentuk

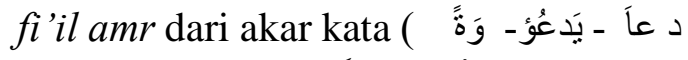

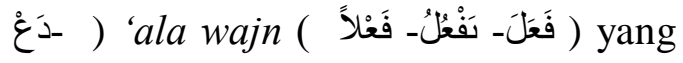
berarti menyeru, memanggil, mengajak, menjamu. Jadi kata ( أدَ ع ) mengandung arti perintah, yaitu serulah atau ajaklah. ${ }^{5}$

Lafal ( أْدَ) merupakan bentuk fi'il amr (kata perintah) kepada Nabi Muhammad SAW untuk menyeru manusia kepada jalan Allah SWT (agama Allah SWT). Dalam ayat itu tidak menyebut maf"ul bihnya (objek). Menurut sebagian mufassir mengatakan bahwa obyek seruan Nabi adalah semua manusia. Ini berarti bahwa Nabi di utus untuk manusia seluruhnya. ${ }^{6}$

Dalam tafsir Al-Maraghi makna ( أُدْعْ ) disebutkan sebagai berikut:

$$
\begin{aligned}
& \text { اي ادع ايهاالرسول من ارسلك اليهم }
\end{aligned}
$$

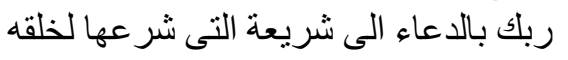

$$
\begin{aligned}
& \text { بوحي الله الذى يوحيه اليك }
\end{aligned}
$$

Yaitu serulah atau ajaklah wahai Rasul (Nabi Muhammad SAW) apa yang Tuhanmu utus kepada mereka dengan seruan atau ajakan untuk menjalankan syari'atNya yang telah ditetapkan kepada

5Zain Fannani, Metode Pendidikan Dalam Al-Qur'an (Kajian Tafsir Surat An-Nahl ayat 125), h. 43 .

6Zain Fannani, Metode Pendidikan Dalam Al-Qur'an, (Kajian Tafsir Surat An-Nahl Ayat 125), h.43.
makhluk-Nya melalui perantara wahyu Allah yang diwahyukan kepadamu. Menurut tafsir AlMaraghi kata ( أدْ عُ ) ini menunjukkan arti ajakan atau seruan untuk menjalankan syari'at Allah melalui Nabi Muhammad. ${ }^{7}$

Sedangkan

dalam

menafsirkan kata (بالحكمة ) menurut M. Quraish Shihab, hikmah antara lain yang paling utama dari segala sesuatu, baik pengetahuan maupun perbuatan. Dia adalah pengetahuan atau tindakan yang bebas dari kesalahan atau kekeliruan. Hikmah juga diartikan sebagai sesuatu yang bila diartikan sebagai sesuatu yang bila digunakan/diperhatikan akan mendatangkan kemaslahatan dan kemudahan yang besar atau lebih besar. $^{8}$

بالحكمة : : بعني بالنبوة و القران Yaitu dengan kenabian dan AlQur'an. Adapun dalam tafsir AlAzhar karangan Hamka, kata hkmah kadang-kadang diartikan orang dengan filsafat. Padahal dia adalah inti yang lebih halus dari filsafat. Filsafat hanya dapat difahamkan oleh orang-rang yang telah terlatih pikirannya dan tinggi

${ }^{7}$ Ahmad Mustafa Al-Maraghi, Tafsir AlMaraghi, (Kairo: Musthofa Al-Bab AlHalab,1946), h.161.

${ }^{8}$ M. Quraish Shihab, Tafsir Al-Misbah, (Jakarta: Lentera Hati, 2002), Vol. VII, h.386. 
pendapat logikanya. Akan tetapi hikmah dapat menarik orang yang belum maju kecerdasannya.dan tidak dapat di bantah oleh orang yang lebih pintar. Kebijaksanaan itu bukan saja dengan ucapan mulut, melainkan termasuk juga dengan tindakan dan sikap hidup. ${ }^{9}$

g gang diartikan pengajaran yang baik, atau pesan-pesan yang baik, yang disampaikan sebagai nasehat. Sebagai pendidikan dan tuntunan sejak kecil. ${ }^{10}$ Dalam mau'idhzah hasanah ini mencakup targhib (seruan ke arah kebaikan dan memberi iming-iming balasan kebaikan) dan tarhib (seruan untuk meninggalkan keburukan dengan memberi peringatan dan ancaman bagi mereka yang melanggar). ${ }^{11}$

Adapun menurut M. Quraish Shihab dalam tafsir AlMisbah yaitu, uraian yang menyentuh hati yang mengantar pada kebaikan. Yang disampaikan itu di sertai dengan pengamalan dan keteladanan dari yang menyampaikannya. $^{12}$

Maka penulis berpendapat bahwa pengertian mauidzah hasanah adalah suatu upaya berdakwah dengan memberikan nasihat yang baik terhadap obyek dakwah (mad'u), dengan harapan hal itu dapat dihayati oleh hati nurani setiap obyek dakwah, bukan

${ }^{9}$ Hamka, Tafsir Al-Azhar, (Jakarta: Pustaka Panjimas, 1983), Juz 13 dan 14, h.321.

${ }^{10}$ Hamka, Tafsir Al- Azhar, h.321.

${ }^{11}$ Ahmad Ibnu Muhammad Ash-Shawy, Hasyiyah Ash-Shawy, (Libanon: Dar Fikr, 2007), Juz II, h.412. h.321.

${ }^{12}$ M. Quraish Shihab, Tafsir Al-Misbah, berdakwah dengan lisan yang kasar sehingga membuat orang yang melihatnya malah menjauh. Oleh karena itu berdebatlah dengan orang yang berbeda pendapat dengan cara yang sebaik-baiknya, yaitu dengan dalil-dalil dan pandangan yang benar serta dengan perkataan yang lemah lembut

Menurut M. Quraish Shihab jadilhum berasal dari kata jidal yang bermakna diskusi atau buktibukti yang mematahkan alasan atau dalih mitra diskusi dan menjadikannya tidak dapat bertahan, baik yang dipaparkan itu diterima oleh semua orang maupun hanya oleh mitra bicara. ${ }^{13}$

Dari beberapa penafsiran diatas tentang Surah An-Nahl ayat 125 ini, ayat ini merupakan ayat dakwah, yang merupakan seruan yang dilakukan oleh Rasulullah kepada umat manusia. Baik kepada mereka yang sudah masuk Islam maupun kepada mereka yang belum masuk Islam (musyrikin). ${ }^{14}$

Maka, ayat ini dipahami oleh sementara ulama sebagai menjelaskan tiga macam metode dakwah yang harus disesuaikan dengan sasaran dakwah (mad'u). Terhadap cendekiawan yang memiliki pengetahuan tinggi diperintahkan menyampaikan dakwah dengan hikmah, yakni berdialog dengan kata-kata bijak sesuai dengan tingkat kepandaian mereka. Terhadap kaum awam, h.387.

${ }^{13}$ M. Quraish Shihab, Tafsir Al-Misbah,

${ }^{14}$ Zain Fannani, Metode Pendidikan Dalam Al-Qur'an (kajian Tafsir Surat An-Nahl Ayat 125), h.45. 
diperintahkan menerapkan

mau'izhah, yakni memberikan

nasihat dan perumpamaan yang

menyentuh jiwa sesuai dengan taraf

pengetahuan mereka yang

sederhana. Sedangkan kepada $A h l$

al-Kitab dan penganut-penganut

agama lain yang diperintahkan

adalah dengan jidal, yaitu

perdebatan dengan cara yang

terbaikmenggunakan logika dan

retorika yang halus, lepas dari

kekerasan dan umpatan. ${ }^{15}$ 


\section{KAJIAN AL-QUR'AN SURAH AN-NAHL AYAT 125 DARI SISI MAKARIM AS- SYARI'AH PERSPEKTIF ETIKA IBNU MISKAWAIH}

Sebelum kajian An-Nahl ayat 125 penulis ingin menjelaskan lebih dahulu pengertian makarim syari'ah. Makarim As-Syari'ah merupakan suatu istilah yang dikenalkan oleh seorang ulama besar yaitu Al-Raghib Al-Isfahani. Menurut Isfahani bahwa dalam setiap ahkam as-syari'ah akan timbul makarim syari'ah. Jadi makarim syari'ah merupakan efek kemuliaan dari setiap ahkam syari'ah. ${ }^{16}$

Makarim
menurut Al-Ryari'ah
sebagaimana yang dikutip oleh Amril Mansur adalah suatu ungkapan terhadap sesuatu yang tidak akan menjauhkan diri dari sifat-sifat Tuhan yang terpuji seperti kebijaksanaan, kebaikan, murah hati, pengetahuan dan kepemaafan. ${ }^{17}$

Makarim as-syari'ah merupakan hasil penyucian jiwa yang diidentikkan dengan segala bentuk prilaku yang baik, termasuk perbuatan baik untuk orang lain di luar diri sendiri. Artinya adalah sebagai akhlak yang menunjukkan bahwa prilaku yang baik dan bijak tidak lagi hanya pada peningkatan kualitas profesional tetapi juga

\footnotetext{
16Penjelasan Dr. Husain Heriyanto dalam mata kuliah Teori Etika Dalam Islam.

${ }^{17}$ Makalah Pendidikan Nilai (Ahkam Syari'ah dan Makarim Syari'ah), Selasa, 14 Februari 2014, h.1.
}

membawa peningkatan kebaikan terhadap orang lain. ${ }^{18}$

Ada tiga hal penting yang di bicarakan dalam surah An-Nahl ayat 125 ini sebagai ahkaam assyari'ah yaitu bilhikmah, mauizhotil hasanah, jaadilhum billatii hiya ahsan. Tiga hal itu merupakan akhlak (etika) dalam berdakwah. Berbicara tentang akhlak, penulis cenderung hendak membahasnya melalui pandangan Ibnu Miskawaih, sebagai seorang bapak etika dalam Islam.

Menurut Ibnu Miskawaih masalah pokok yang dibicarakan dalam kajian akhlak adalah kebaikan (al khair), kebahagiaan (as sa'adah) dan keutamaan (al fadhilah). Kebaikan adalah suatu keadaan dimana telah sampai kepada batas akhir dan kesempurnaan wujud. Kebaikan ada dua, yaitu kebaikan umum muatanndan kebaikan khusus. Kebaikan umum adalah kebaikan bagi seluruh manusia dalam kedudukannya sebagai manusia atau dengan kata lain, ukuranukuran kebaikan yang di sepakati oleh seluruh manusia. Kebaikan khusus adalah kebaikan bagi seseorang secara pribadi. Kebaikan kedua inilah yang disebut kebahagiaan. Karena itu, dapat

18Makalah Pendidikan Nilai (Ahkam
Syari'ah dan Makarim Syari'ah) h.2. 
dikatakan bahwa kebahagiaan itu berbeda-beda bagi setiap orang. ${ }^{19}$

Kemudian Ibnu Miskawaih men̋̈-yinggung tentang al hikmah (kebijaksanaan). Menurutnya al hikmah adalah keutamaan jiwa rasional (al nafs al nathiqoh) yang mengetahui segala maujud (al maujudat), baik hal-hal yrang bersifat ketuhanan (al umur al ilahiyyah) maupun hal-hal yang bersifat kemanusiaan (al umur al insaniyyah). Pengetahuan ini membuahkan pengetahuan rasional (al mauqulah) yang mampu memberi keputusan antara yang wajib dilaksanakan dengan yang wajib ditinggalkan. Di samping itu, Ibnu Miskawaih mengatakan kebijaksaan adalah pertengahan (al wasath) antara kelancangan (al safh ) dan kebodohan (al baladah). Kelancangan yang dimaksud adalah penggunaan daya pikir yang tidak tepat. Sedangkan kebodohan adalah membekukan dan mengesampingkan daya pikir walau sebetulnya mempunyai kemampuan. Dengan demikian yang menjadi tekanan Ibnu Miskawaih disini bukan pada sisi kualitas daya pikir itu melainkan pada sisi kemauan untuk menggunakannya. ${ }^{20}$

Menurut analisis penulis kaitan hikmah ayat ini dengan apa yang dikemukakan oleh Ibnu Miskawaih tadi dari segi makaariim as-syari'ah (kemuliaan syari'at) adalah bahwa seorang

${ }^{19}$ Nizar, Pemikiran Etika Ibnu Miskawaih, (Jurnal), (Universitas Sulawesi Barat), h.39.

${ }^{20}$ Nizar, Pemikiran Etika Ibnu Miskawaih, penda'i menyeru kepada mad'u (objek dakwah) dengan cara-cara yang bijaksana, menggunakan jiwa atau akal yang rasional agar mudah di terima oleh nalar mad'u untuk menuju pengenalan kepada jalanjalan yang di ridoi Tuhan sehingga nantinya diharapkan mad'u mempunyai kesadaran bahwa ia punya dua hubungan yaitu hubungan vertikal kepada Tuhannya (hablumminallaah) dan hubungan horizontal kepada sesama manusia (hablumminannaas), yang mempunyai derajat yang sama yaitu sama-sama sebagai makhluk Tuhan. Ada hal yang perlu di ingat bahwa manusia itu heterogen.

Mengenai manusia Ibnu Miskawaih berkata bahwa: “ substansi manusia mempunyai aktivitas yang khas, yang tak ada pada lainnya di dunia ini. Manusia merupakan benda alam yang paling mulia. Namun bila dia tidak melakukan tindakan yang khas pada substansinya, maka dia, seperti kami katakan, menjadi seperti seekor kuda yang, jika tidak lagi berprilaku kuda, digunakan persis seekor keledai untuk membawa muatan, dan kalau begini lebih baik mati ketimbang hidup". ${ }^{21}$ Inilah manusia yang tidak menggunakan daya nalar akalnya, derajatnya akan jauh lebih hina daripada hewan. Karenanya seruan dakwah bilhikmah ini merupakan seruan agar manusia mengikuti jalan-jalan Tuhan yang nantinya

${ }^{21}$ Ibnu Miskawaih, Menuju kesempurnaan Akhlak, (Terjemahan Helmi Hidayat), (Bandung: Mizan, 1994), Cet. II, h.60. 
akan mengangkat derajatnya, karena ia menggunakan daya nalarnya. Mereka yang telah mengikuti jalan-jalan Tuhan tadi saling mencintai dan menyayangi dalam satu ikatan, yaitu ikatan ukhuwah Islamiyyah dari berbagai penjuru dunia. Mengenai hal ini penulis mengutip kembali uraian yang dipaparkan oleh Ibnu Miskawaih yang akan penulis uraikan pada pada paragraf di bawah ini.

Beliau SAW, mewajibkan pula masyarakat untuk berkumpul dua kali setiap tahun nya di sebuah lokasi ibadah: tanah lapang. Hal ini pun dimaksudkan agar mereka dapat tertampung, sehingga mereka bisa saling bertemu dan meningkatkan persahabatan dan di liputi rasa cinta yang mempersatukan mereka. Beliau juga mewajibkan paling tidak sekali seumur hidup nya manusia berkumpul di sebuah tempat suci, kota Mekkah. Sengaja beliau menentukan waktu yang pasti dalam melaksanakan kewajiban yang sekali dalam seumur hidup ini, dengan tujuan memberikan mereka kesempatan yang luas. Manusia dari berbagai negara yang saling berjauhan dapat berkumpul, sebagaimana masyarakat sebuah kota, dan dapat mencapai cinta, masyarakat yang baik dan bahagia. Dengan fithrah manusia yang menghendaki persahabatan ini, mereka bertemu untuk mengupayakan kebaikan-kebaikan bersama, memperbaharui ketaatan merekia pada agama, untuk mengagungkan Allah atas hidayah yang telah dilimpahkan-Nya pada mereka, juga untuk terus bersamasama memeluk agama lurus yang telah mempersatukan mereka dalam ketaatan kepada-Nya. $^{22}$ 


\section{ETIKA DAKWAH NABI SAW}

Sebagai bukti realita nyata dari etika dakwah dalam Al-Qur'an Surat An-Nahl ayat 125 tadi, kita dapat melihat kembali bagaimana cara Rasulullah berdakwah, yang membawa hasil cemerlang yang luar biasa. Dalam menyampaikan risalah kenabian nya, Rasulullah menyampaikan dakwah nya dengan penuh etika, sehingga beliau berhasil menyampaikan misi kerasulan nya. Beliau berhasil merubah watak bangsa Arab yang dekadensi moral menjadi bangsa yang penuh dengan keberkahan. Beliau berhasil merubah dari bangsa yang suka berperang antar suku menjadi bangsa yang bersatu dalam naungan satu ikatan iman.

Adapun kode etika dakwah Nabi SAW secara singkat dapat dijelaskan sebagai berikut.$^{23}$

1. Tidak memisahkan antara ucapan dan perbuatan.

$$
\text { Dalam menjalankan }
$$

dakwah, Rasulullah SAW tidak pernah memisahkan antara apa yang beliau katakan dengan apa yang beliau kerjakan. Artinya, apa yang beliau perintahkan beliau pun mengerjakannya, dan apa yang beliau larang beliau meninggalkannya. Misalnya, dalam hal perintah beliau untuk shalat, beliau bersabda: "Shalatlah kalian seperti kalian melihat diriku shalat”. Demikian pula dalam

${ }^{23}$ Uraian berikut ini seluruhnya mengutip dari buku Ali Mustafa Yaqub, Sejarah dan Metode Dakwah Nabi, (jakarta: Pustaka Firdaus, 2000), Cet. II, h.36-47, kecuali kutipan ayat Al-Qur'an dan Terjemahnya. masalah haji, beliau bersabda: "Lakukanlah ibadah haji kalian dengan mencontoh ibadah hajiku".

Etika dakwah seperti ini merupakan suatu keharusan bagi para da'i. Tanpa hal itu sulit rasanya dakwah mereka akan berhasil. Allah sendiri mengecam orang- orang yang hanya pandai berbicara tetapitidak pernah melakukannya. Firman Allah dalam Surah Al-Shaff ayat 2-3:

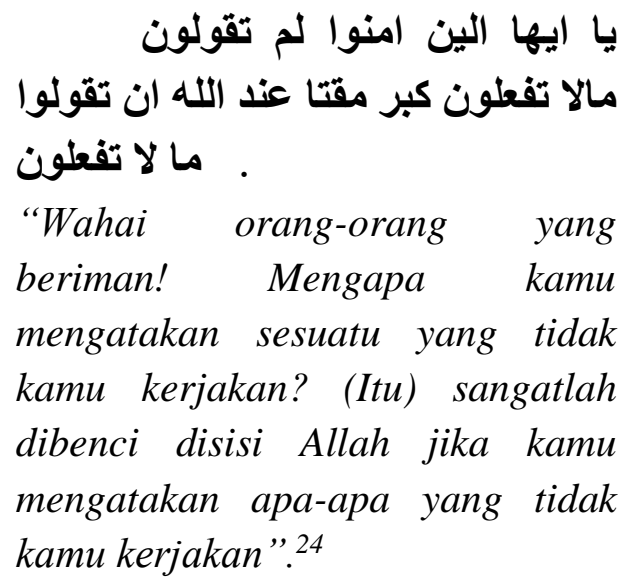
kamu kerjakan? (Itu) sangatlah dibenci disisi Allah jika kamu mengatakan apa-apa yang tidak kamu kerjakan". ${ }^{24}$

2. Tidak melakukan toleransi agama. Toleransi (tasamuh) memang dianjurkan Islam. Tetapi dalam batas-batas tertentu dan tidak menyangkut batas agama (aqidah). Dalam masalah agama (aqidah), Islam memberi garis tegas untuk tidak bertoleransi, kompromi, dan sebagainya.

3. Tidak mencerca sesembahan lawan. Pada waktu Nabi SAW masih tinggal di Mekkah, orangorang musyrikin mengatakan bahwa nabi SAW sering mencerca berhala-berhala sesembahan mereka. Akhirnya secara emosional mereka mencerca Allah,

${ }^{24}$ Al-Qur'an dan Terjemahnya, h.805 
sesembahan Nabi SAW. Bahkan mereka mengultimatum Nabi. Kata mereka, "Wahai Muhammad hanya ada dua pilihan, kamu tetap mencerca tuhan-tuhan kami, atau kami akan mencerca tuhanmu."

Orang-orang muslim pada saat itu juga sering mencerca berhalberhala sesembahan orang musyrikin . Akhirnya, karena hal itu menyebabkan orang-orang musyrikin mencerca Allah, Allah menurunkan ayat-Nya dalam Surah Al-An'am ayat 108 yang berbunyi:
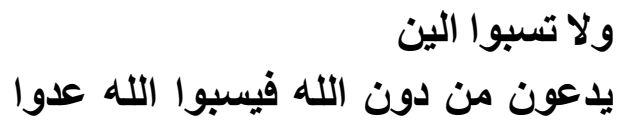
بغير علم

"Dan janganlah kamu memaki sesembahan yang mereka sembah selain Allah, karena mereka nanti akan memaki Allah dengan melampaui batas tanpa dasar pengetahuan. "25.

4. Tidak melakukan diskriminasi.

Dalam menjalankan tugas dakwah, Nabi SAW tidak diperkenankan melakukan diskriminasi sosial diantara orangorang yang didakwahi. Beliau tidak diperkenankan mementingkan orang-orang kelas elit saja, sementara orang-orang kelas bawah dinomorduakan.

Ketika Nabi SAW masih berada di Mekah, suatu saat beliau mengajarkan agama Islam kepada orang-orang yang miskin dan berasal dari rakyat jelata, antara lain Khubab bin al-Arit, 'Abdullah

${ }^{25}$ Al-Qur'an dan Terjemahnya, h.112. bin Mas'ud, shuhaib al-Rumi, 'Ammar bin Yassir, Salman alFarisi dan Bilal al-Habsyi. Tibatiba datang tokoh-tokoh suku Quraisy menghadap Nabi SAW. Mereka antara lain al-Arqa bin Habis al-Tamimi, dan Uyainah bin Hishn al-Fazari.

Kepada Nabi SAW mereka berkata, "Kami ini adalah orang orang terhormat dikalangan suku kami. Apabila kami duduk dalam satu majelis dengan kamu, maka kami tidak ingin suku kami melihat kami duduk bersama orang-orang seperti Bilal, Shuhaib dan kawankawannya. Oleh karena itu, suruhlah mereka itu pergi meninggalkan kita',

Karena Nabi SAW menginginkan agar tokoh-tokoh musyrikin Quraisy iitu mau mendengarkan ajaran Islam, sehingga mereka mau masuk Islam, maka kemudian mereka menyetujui permintaan mereka itu. Namun mereka juga tidak mau begitu saja tanpa adanya perjanjian tertulis untuk itu. Akhirnya Nabi SAW menyetujui untuk membuat perjanjian, dan memanggil Ali bin Abi Thalib untuk menulis perjanjian itu.

Mendengar pembicaraan Nabi SAW dengan tokoh-tokoh musyrikin Quraisy itu, Bilal dan kawan-kawannya segera pergi meninggalkan Nabi SAW dan kemudian duduk di salah sebuah sudut tanpa disuruh lebih dahulu. Dan setelah Ali selesai menulis perjanjian itu, Allah menurunkan ayat-Nya, Surah Al-An'am ayat 52: 


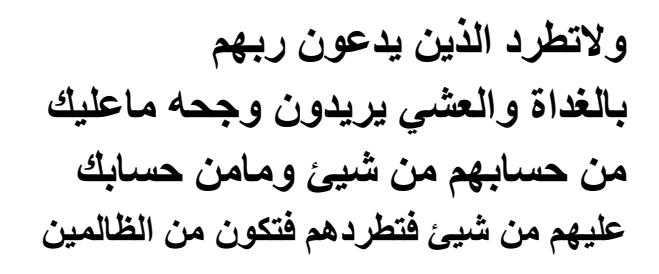

"Janganlah engkau mengusir orang-orang yang menyeru Tuhannya di pagi dan petang hari, mereka mengharapkan keridaanNya, engkau tidak memikul tanggung jawab sedikit pun terhadap perbuatan mereka dan mereka tidak memikul tanggung jawab sedikit pun terhadap perbuatanmu, yang menyebabkan engkau (berhak) mengsir mereka, sehingga engkau termasuk orangorang yang zalim". ${ }^{26}$

5. Tidak memungut imbalan.

Suatu hal yang sangat penting dalam dakwah Nabi SAW, maupun Nabi-nabi sebelumnya, beliau tidak pernah memungut imbalan dari pihak-pihak yang didakwahi. Beliau hanya mengharapkan imbalan dari Allah saja. Sikap beliau ini berdasarkan perintah Allah SWT dalam Surah Saba' ayat 47 sebagai berikut:

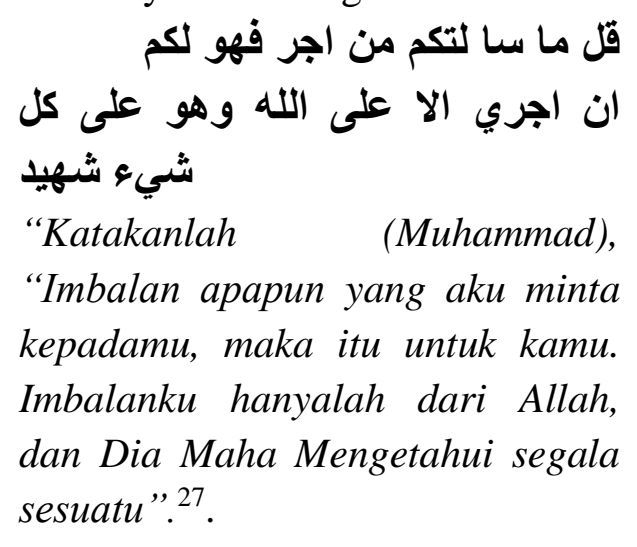

"Katakanlah

(Muhammad),

"Imbalan apapun yang aku minta kepadamu, maka itu untuk kamu. Imbalanku hanyalah dari Allah, dan Dia Maha Mengetahui segala sesuatu". ${ }^{27}$.

${ }^{26}$ Al-Qur'an dan Terjemahnya, h.179

27, Al-Qur'an dan Terjemahnya, h.346.
Sikap da'i yang tidak memungut imbalan dari pihak-pihak yang didakwahi ini akan menjadikan dakwahnya memiliki kharisma, sementara ia sendiri tidak akan terjerat beban moral apapun, kecuali hanya kepada Allah saja.

Namun apakah secara mutlak orang yang melakukan dakwah tidak boleh menerima sama sekali dari pihak-pihak yang didakwahi? Disini para ulama berbeda pendapat menjadi tiga kelompok mazhab. Kelompok pertama, terdiri dari para ulama mazhab Hanafi, dan lain-lain. Mereka berpendapat bahwa memungut imbalan dalam menyiarkan ajaran Islam itu hukum nya haram secara mutlak, baik ada perjanjian sebelumnya untuk itu maupun tidak. Kelompok kedua, terdiri antara lain imam Malik bin Anas, imam Syafi'i dan lain-lain. Mereka berpendapat bahwa memungut imbalan dalam menyebarkan ajaran Islam itu hukum nya boleh, baik ada perjanjian sebelumnya maupun tidak. Kelompok ketiga, antara lain terdiri dari al-Hasan al-Bashr, alSya'bi, Ibnu Sirrin dan lain-lain. Mereka berpendapat apabila ada perjanjian sebelum nya untuk memungut imbalan dalam mengajarkan agama Islam, maka hal itu hukumnya haram. Tetapi apabila tidak ada perjanjian apaapa, kemudian orang yang mengajarkan agama Islam itu diberi imbalan, maka itu hukumnya boleh.

6. Tidak mengawani pelaku maksiat.

Dalam menjalankan dakwah ternyata Nabi SAW tidak pernah 
berkawan, apalagi berkolusi, dengan para pelaku maksiat. Hal ini bukan karena pada masa Nabi SAW tidak ada orang yang berbuat maksiat, melainkan begitu itulah etika dakwah. Pada masa Nabi SAW ada orang yang berbuat maksiat. Misalnya ketika seorang sahabat bernama Martsad bin Abu Martsad hendak menikahi seorang wanita bernama Anaq dan wanita ini diketahui sebagai seorang pezina, Nabi SAW melarang martsad untuk menikahi wanita tersebut.

Mengawani pelaku maksiat akan berdampak serius, karena pelaku maksiat tadi akan beranggapan bhwa perbuatannya itu direstui oleh da'i yang mengawaninya itu. Tetapi apabila ia sudah meninggalkan maksiatnya, bertaubat dan sebagainya, tentulah masalah nya menjadi lain, karena itu bukan lagi pelaku maksiat.

Nabi Muhammad SAW justru mengemukakan para ulama atau da'i yang berakrab-akraban dengan pelaku maksiat akan dilaknat oleh Allah. Beliau menceritakan bahwa ketika orangorang Bani Israil terjerumus kedalam lembah maksiat, para ulama mereka berusaha mencegahnya. Namun mereka tidak mau meninggalkan maksiat itu. Para ulama itu kemudian mengakrabi para pelaku maksiat itu, mereka dikawani, diajak makan-makan dan minum-minum bersama dan lain-lain. Karena para ulama dan pelaku maksiat itu sudah saling akrab, akhirnya Allah membuat mereka makin bertambah mesra dan saling menyayangi kemudian mereka semuanya, baik yang ulama maupun pelaku maksiat dilaknat oleh Allah.

Nabi SAW menceritakan hal ini dalam rangka menafsiri firman Allah, ayat 78-79 Surah AlMaidah sebagai berikut:

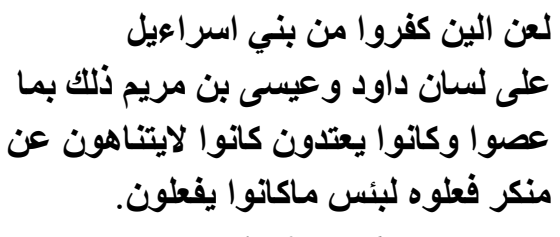

"Orang-orang kafir dari Bani Israil telah dilaknat melalui lisan (ucapan) Dawud dan Isa puta Maryam. Yang demikian itu karena mereka durhaka dan selalu melampaui batas. Mereka tidak saling mencegah perbuatan mungkar yang selalu mereka perbuat. Sungguh, sangat buruk apa yang merekaperbuat". ${ }^{28}$

7. Tidak menyampaikan hal-hal yang tidak diketahui

Seorang da'i adalah penyampai ajaran Islam. Sementara ajaran itu berisi hal-hal gtentang halal-haram dan sebagainya. Da'i yang menyampaikan sesuatu hukum, sementara ia tidak mengetahui hukum itu pastilah akan menyesatkan orang lain. Ia lebih baik mengatakan tidak tahu atau wallahu a'lam apabila ia tidak tahu jawaban suatu masalah. Ia juga tidak boleh asal menjawab, dan sal menurut seleranya sendiri, karena masalah yang ditanyakankepada da'i tentulah maslah keagamaan yang harus ada

${ }^{28} \mathrm{Al}$-Qur'an dan Terjemahnya, Departemen Agama RI, (Surabaya: Karya Agung, 2006), Edisi Revisi, h.160-161. 
dalilnya baik dari Al-Qur'an maupun Hadits.

Dalam hal ini Allah menegaskan dalam FirmanNya Surah Al-Isra ayat 36:

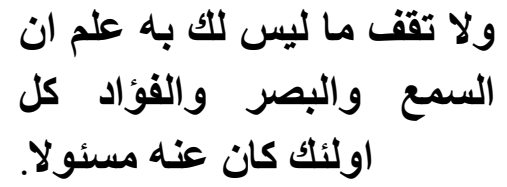

"Dan janganlah kamu mengikuti sesuatu yang tidak kamu ketahui. Karena pendengaran, penglihatan, dan hati nurani, semua itu akan dimintakan

pertanggungjawabannya", ${ }^{29}$ 


\section{E. KESUKSESAN DAKWAH NABI SAW DALAM LINTASAN SEJARAH ISLAM}

Rasulullah SAW ketika di Mekkah begitu banyak menghadapi tantangan dan rintangan sampai akhirnya beliau dan kaum muslimin melakukan hijrah. Beliau dan kaum muslimin pertama-tama melakukan hijrah ke Ethiopia. Berkat kepandaian ja'far bin Abi Thalib (salah seorang sahabat Rasul yang terpilih melakukan hijrah) dalam bernegosiasi dengan para raja-raja dan para pemuka istana. Ja'far melukiskan tentang sosok cemerlang Rasulullah, menjelaskan prinsip-prinsip Islam yang agung dan membacakan beberapa ayat dari surah Maryam, akhirnya para raja dan pemuka istana merasa tersentuh hati mereka. Mereka pun akhirnya memberi kenyamanan bagi para muhajir tersebut. Namun di sisi lain hal ini membuat orangkafir Quraisy memutuskan hubungan dengan Bani Hasyim (keluarga dan pendukung Rasulullah SAW). Ini menjadi tekanan yang berat bagi Nabi dan kaum muslimin saat itu ${ }^{30}$

Keadaan ini menyebabkan Rasulullah hijrah ke Thaif. Disana Rasulullah menyeru orang-orang Thaif kepada Islam. Namun orangorang bodoh dan jahil di kota itu berhamburan keluar dari segala penjuru. Mereka melontarkan

${ }^{30}$ Allamah Sayyid Muhammad Husain Thabatha'i, Inilah Islam: Upaya Memahami Konsep Islam Secara Mudah, (Terjemahan Ahsin Mohammad), (Jakarta: Pustaka Hidayah, 1992), Cet. I, h.81-82. sumpah serapah, melempari Rasulullah dengan batu, dan akhiranya mereka memaksa Rasulullah keluar dari kota itu ${ }^{31}$. Beliau pun akhirnya kembali ke Mekkah.

Di Mekkah nyawa beliau terancam. Para pemimpin Mekkah bertemu guna menyusun sebuah rencana di majelis mereka, yang dikenal dengan sebutan DarunNadwah. Mereka berencana membunuh Rasulullah SAW. Namun, kehendak Allah mengalahkan kehendak mereka dan menjadikan rencana mereka sekadar lamunan belaka. Allah SWT mewahyukan kepada Rasulullah SAW tentang rencana mereka itu dan memerintahkan beliau meninggalkan Mekkah di malam hari dan hijrah ke Madinah $^{32}$.

Setelah tiba dan di terima penduduk Yatsrib (Madinah), Nabi resmi menjadi pemimpin kota itu. Babak baru dalam sejarah Islam pun dimulai. Berbeda dengan periode Mekah, pada periode Madinah, Islam merupakan kekuatan politik. Ajaran Islam yang berkenaan dengan kehidupan masyarakat banyak turun di Madinah. Nabi Muhammad

${ }^{31}$ Allamah Sayyid Muhammad Husain Thabatha'i, Inilah: Upaya Memahami Konsep Islam Secara Mudah, h.82.

${ }^{32}$ Allamah Sayyid Muhammad Husain Thabhata'i, Inilah Islam: Upaya Memahami Seluruh Konsep Islam Secara Mudah, h.82-83. 
mempunyai kedudukan bukan saja sebagai kepala agama, tetapi juga sebagai kepala negara. Dengan kata lain dalam diri Nabi terkumpul dua kekuasaan, kekuasaan spiritual dan kekuasaan duniawi. Kedudukannya sebagai Rasul secara otomatis merupakan kepala negara ${ }^{33}$

Dalam rangka memperkokoh masyarakat dan negara baru itu, ia segera meletakkan dasar-dasar kehidupan bermasyarakat, yaitu:

1. Pembangunan masjid.

Pada saat itu, masjid selain sebagai tempat shalat, juga sebagai tempat mempersatukan kaum muslimin dan mempertalikan jiwa mereka. Juga sebagai tempat bermusyawarah dan sebagai pusat pemerintahan.

2. Ukhuwwah Islamiyyah (persaudaraan antara sesama muslim).

Di Madinah Nabi mempersaudarakan golongan Muhajirin (orang-orang muslim Mekkah yang ikut hijrah dari Mekkah ke Madinah) dengan golongan Anshar (penduduk Madinah yang sudah masuk muhajirin). Ini berati Rasul telah menciptakan bentuk persaudaraan berdasarkan agama menggantiakn bentuk persaudaraan berdasarkan darah. Islam dan ikut membantu kaum

3. Hubungan persahabatan dengan pihak-pihak lain yang tidak beragama Islam.

Di Madinah saat itu, selain terdapat orang-orang Arab Islam, juga terdapat golongan masyarakat Yahudi dan orangorang Arab yang masih menganut kepercayaan agama nenek moyang mereka. Agar stabilitas masyarakat dapat di wujudkan, Nabi Muhammad mengadakan ikatan perjanjian dengan mereka. Sebuah piagam yang menjamin kebebasan beragama orang-orang Yahudi sebagai suatu komunitas di keluarkan. Setiap golongan masyarakat memiliki hak tertentu dalam bidang politik dan keagamaan. Kemerdekaan beragama dijamin, dan seluruh anggota masyarakat berkewajiban mempertahankan keamanan negeri itu terhadap serangan dari luar. Dalam perjanjian itu jelas di sebutkan bahwa Rasulullah menjadi kepala pemerintahan karena sejauh menyangkut peraturan dan ketertiban umum, otoritas mutlak di berikan kepada beliau. Dalam bidang sosial beliau juga meletakkan dasar persaman antara sesama manusia. Perjanjian ini dalam pandangan ketetatanegaraan sekarang sering disebut dengan Konstitusi Madinah ${ }^{34}$. Setelah itu Rasulullah pun berhasil mengusai kota Mekkah kembali

${ }^{33}$ Badri Yatim, Sejarah Peradaban Islam, (Jakarta: Rajawali Pers, 2000), Cet. X, h.25.
${ }^{34}$ Badri Yatim, Sejarah Peradaban Islam, h.25-26. 
dengan cara-cara yang damai yang dikenal dengan peristiwa pembebasan kota Mekkah (Fathul Makkah). Dan Islam pun dapat disebarkan dengan dakwah kedaerah-daerah lain (Selain jazirah Arab) bahkan sampai keseluruh dunia. Itulah satu contoh dakwah yang penuh dengan keteladanan etika sehingga Rasulullah sukses dalam menjalan Risalah Kenabiannya.

Antony Black mengatakan bahwa: "Tujuan Nabi Muhammad sejak piagam Madinah dan fase paling awal dakwahnya di Madinah, adalah untuk mengubah konfederasi kesukuan menjadi sebuah masyarakat baru yang dikendalikan oleh ajarannya tentang moral. Nabi Muhammad menciptakan monoteisme baru yang cocok dengan kebutuhan kontemporer masyarakat kesukuan, selama masyarakat itu memang ingin berkembang menjadi lebih besar.Ia memungkinkan mereka mencapai transisi itu secara berkelanjutan dari politeisme ke monoteisme, dandari kesukuan menuju nasionalisme kemudian internasionalisme". 35

${ }^{35}$ Antony Black, Pemikiran Politik Islam Dari Masa Nabi Hingga Masa Kini (Terjemahan Abdullah Ali dan Mariana Ariestyawati), (Jakarta: PT serambi Ilmu Semesta, 2006), Cet. I, h.37. 


\section{KESIMPULAN}

Al-Qur'an memberikan tuntunan bahwa dalam menyeru manusia menuju kepada jalan Tuhan dengan tiga hal, yaitu, bil hikmah, mauizoh hasanah dan mujadalah billati hiya ahsan. Itu merupakan landasan utama dalam berdakwah sebagai pedoman hukum syariah (Ahkaam As-Syarii'ah) dalam menjalankan misi dakwah. Dalam hal ini contoh terbaik adalah Rasulullah Muhammad SAW. Beliau telah berhasil menyampaikan risalah Islam keseluruh penjuru dunia dengan etika teladan nya yang sangat indah. Sehingga beliau dalam waktu kurang lebih 23 tahun berhasil menyampaikan dakwah nya. Masyarakat Arab yang saat itu dikenal keras, dan sering kali saling berperang antar suku

\section{DAFTAR PUSTAKA}

Al-Qur'an dan Terjemahnya, Departemen Agama RI, (Surabaya: Karya Agung, 2006), Edisi Revisi.

As-Shawy, Ahmad Ibn Muhammad, Hasyiyah Ash-Shawy, (Libanon: Dar al-Fikr, 2007), Juz II.

Al Maraghi, Ahmad Mustafa, Tafsir AlMaraghi, (Kairo: Musthofa Al-Bab Al-Halab, 1946.

Black, Antony, Prof. Dr., Pemikiran Politik Islam Dari Masa Nabi Hingga Masa Kini, (Terjemahan Abdullah Ali dan Mariana Ariestyawati), (Jakarta: PT Serambi Ilmu Semesta, 2006), Cet. I.

Ekawati, Erna, Metode Komunikasi Dakwah Dalam Perspektif Hadits, akhirnya lambat laun menjadi bangsa yang maju berperadaban (masyarakat Madani) yang tonggak utamanya adalah berdirinya negara Madinah.

Rasulullah telah memberi contoh yang terbaik bagi kita dan hasil dari dakwah beliau kita bisa mengenal Islam. Dari Ahkaam As-Syarii'ah yang beliau jalankan dengan baik membawa dampak Makaarim As-Syarii'ah yang begitu indah yang dapat disaksiakan oleh semua orang hingga saat ini. Karena Al-Qur'an Surah An-Nahl ayat 125 ini begitu memberikan inspirasi yang kuat bagi para penda'i jika benar-benar dijalankan dengan baik yang membawa kepada rahmatan lil alamiin seperti halnya yang telah dicontohkan oleh Rasulullah SAW.

(Jurnal), (Jakarta, UIN Syarif Hidayatullah,: Hikmah, 2012), Vol. VI.

Fannani, Zain, Metode Pendidikan Dalam Al-Qur'an, (Skripsi), (Kajian Tafsir Surat An-Nahl Ayat 125), (Skripsi), (Jakarta, UIN Syarif Hidayatullah: 2014).

Hamka, Prof. Dr., Tafsir Al-Azhar, (Jakarta: Pustaka Panji Mas, 1983), Juz XII-XIV, Cet. II.

Miskawaih, Ibnu, Menuju Kesempurnaan Akhlak, (Terjemahan Helmi Hidayat), (Bandung: Mizan, 1994), Cet. II. 
Makalah Pendidikan Nilai (Ahkam Syari'ah dan Makarim Syari'ah), Selasa, 14 Februari 2014, online.

Nizar, Pemikiran Etika Ibnu Miskawaih, (Jurnal), (Universitas Sulawesi Barat).

Shihab, M. Quraish, Prof. Dr., MA., Tafsir Al-Misbah, (Jakarta: Lentera Hati, 2002), Vol VII.

Sayyid Muhammad Husain Thabatha'i, Allamah, Inilah Islam: Upaya
Memahami Seluruh Konsep Islam Secara Mudah, (Terjemahan Ahsin Mohammad), (Jakarta: Pustaka Hidayah, 1992), Cet. I.

Yatim, Badri, Dr., MA., Sejarah Peradaban Islam, (Jakarta: Rajawali Pers, 2000), Cet. X.

Yakub, Ali Mustafa, Prof., Sejarah Dan Metode Dakwah Nabi, (Jakarta: Pustaka Firdaus, 2000), Cet. II. 